\title{
Students' Perception of The Implementation of Content and Language Integrated Learning (CLIL) at Senior High School
}

\author{
Amira Muflicha Daraini', Endang Fauziati², Dewi Rochsantiningsih3 \\ DOI: $10.35445 /$ alishlah.v13i1.404
}

\begin{abstract}
Article Info
Abstract

Keywords:

CLIL

Qualitative research

Students' perception

This research scrutinized the students' perception of Content and Language Integrated Learning (CLIL) in the teaching and learning process. A qualitative approach as a primary framework was employed with a case study method. Twenty students were involved in this research. The information was gathered through questionnaires and interviews. Of the twenty participants, only three participated in the interview session. The results reveal that most students gave tremendous perceptions of CLIL implementation, understanding the teachers' instructions, being comfortable at some point in the class, and enriching their vocabulary. The findings of the study are envisioned to bring light to other teachers to reflect and develop themselves. Moreover, the study aimed to contribute to the schools' policy-making, which means undertaking the CLIL program.
\end{abstract}

Kata kunci:

CLIL

Penelitian kualitatif

Persepsi siswa

\begin{abstract}
Abstrak
Penelitian ini mengkaji persepsi siswa tentang Content and Language Integrated Learning (CLIL) dalam proses belajar mengajar. Pendekatan kualitatif sebagai kerangka kerja utama digunakan dengan metode studi kasus. Dua puluh siswa dilibatkan dalam penelitian ini. Data dikumpulkan melalui kuesioner dan wawancara. Seluruh peserta mengikuti sesi wawancara. Hasil penelitian mengungkapkan bahwa sebagian besar siswa memberikan persepsi yang luar biasa tentang penerapan CLIL; memahami instruksi guru, merasa nyaman di kelas, dan memperkaya kosakata mereka. Hasil penelitian ini diharapkan dapat memberikan penerangan bagi guru lain untuk merefleksikan dan mengembangkan diri. Selain itu, penelitian ini juga sebagai kontribusi dalam pembuatan kebijakan sekolah yang menjalankan program CLIL.
\end{abstract}

\section{INTRODUCTION}

An innovative approach is needed to teach a foreign language in the educational process (Herrarte \& Beloqui, 2015). The idea of a CLIL program was born around twenty years ago across Europe to satisfy the expectations of globalization, within which people have to be compelled to communicate effectively. In the 1990s, the implementation of CLIL began to become popular in Europe. Since then, several other schools, such as European and Indonesian, have adopted CLIL

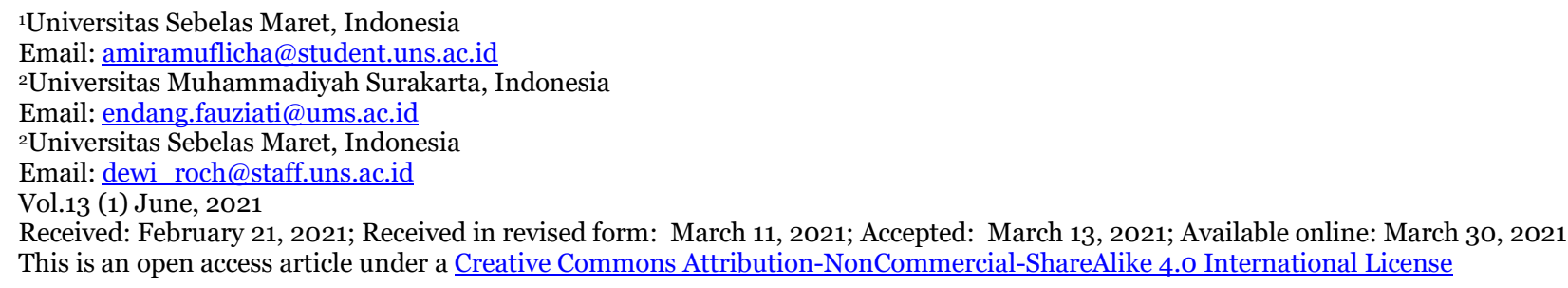


programs as an innovative approach to teaching foreign languages in their educational system (Herrarte \& Beloqui, 2015). The aim was to enable the students to improve both target language and content skills.

Content and Language Integrated Learning (CLIL) is the instructional process of the content subject that requires foreign language implementation as the medium of delivering the materials (De Zarobe, 2013). Besides, CLIL has been defined as an umbrella term that refers to "any dual-focused educational context in which an additional language is used as a medium for teaching and learning non-language content, thus not usually the first language of the learners involved" (Herrarte \& Beloqui, 2015).

Some schools, unconsciously, have been implementing the concept of CLIL, such as Tallinn English School (Dvorjaninova \& Alas, 2018) in Indonesia. The implementation of CLIL in Indonesia is commonly recognized as a bilingual school. Since 2013, the use of CLIL has been known to help in teaching both English and Indonesian. CLIL has become the standard of bilingual learning in Indonesia and has obtained more recognition. In Indonesia, primary and secondary schools, labelling themselves with the international standard, have applied such a learning model. Those schools use both Indonesian and English as a means to teach mathematics and science subjects. In practice, English or alternative foreign languages are often utilized by those schools in the international environment as the instruction means for specific subjects.

Some previous studies about the implementation of CLIL had been conducted by McDougald (2015), Syzdykbayeva (2017), Tachaiyaphum and Sukying (2017), and Campillo et al. (2019). According to several previous studies, numerous researchers are exploring the teachers' perception of CLIL implementation. The analysis indicated that the CLIL was helpful for teachers (Johnson, 2012; Puspitasari, 2016; Tachaiyaphum and Sukying, 2017; McDougald, 2015) because it could benefit the students in learning content and language. However, there is a limited study examining students' perception of CLIL implementation in the classroom. Therefore, this study tried to fill the gap by investigating the students' perception of CLIL implementation in the teaching and learning process at senior high school.

\section{METHODS}

The study was undertaken as a case study to probe into in-depth details of the issue. A case study is a methodology in which the researcher investigates in depth a program, occasion or event, activity, process on at least one person (Creswell \& Creswell, 2017). There is a population that can be defined as a bunch of people with similar characteristics. For example, in this case, the teachers' population would be made up of all teachers. Then, the population of this research is all teachers of senior high schools. Hence, a population can be small or large. The choice of involving a population should be based on what group a researcher might want to think about (Creswell \& Poth, 2016). This study's population was the second-grade students of a Senior High School in Surakarta, Central Java of Indonesia. They use English in the teaching and learning process in almost all school subjects except Indonesian, Arabic, Javanese, and Islamic education.

The participants of the study were chosen purposively regarding the objective of the study. Purposive sampling can be exemplified as purposively picking a specific sample based on the requirements (properties, traits, characteristics, and criteria). All students completed the questionnaire as the participants of this research and were involved in the interview session.

The researcher disseminated the questionnaire to the twenty students in the school before the interview. The questionnaire consists of fifteen questions written in English. To finish the questionnaire, most participants took less than 15 minutes. Furthermore, the researcher interviewed twenty students to discover more comprehensive data. It was executed in Indonesian so that the participants can furnish more constitutive details. Five questions were given during the interview. Each participant spent 20 minutes in the interview. 
The questionnaire and interview questions of the study were adopted from Lee (2006). The interview questions were done to collect the information (Phellas et al., 2011). The data obtained from the questionnaire were analyzed to reveal the students' perception of CLIL implementation. The analysis was based on the given score on the Likert scale (Ockert, 2005). The data were analyzed to help the researcher to interpret crucial characteristics of the issue effectively. Furthermore, the data were checked and ordered to define whether the learners concurred or differed about the school's CLIL implementation.

Subsequently, the interview data confirmed the students' perception of CLIL implementation extracted from the questionnaire. Besides, the interview data were functioned to reinforce and enhance the information collected from the questionnaire.

\section{FINDINGS AND DISCUSSION}

There are 20 participating respondents in this research. All of them perceived that they envisioned the goals or objectives of CLIL in their school. Of those who understood the objectives of CLIL, half (50\%) responded that CLIL helps learners improve not only Indonesian but also English. The rest participants apprehended that CLIL is only helpful for students to develop English. Additionally, and no participant thought that CLIL was too meaningful for students to develop Indonesian.

Regarding the instructional language(s)to teach Indonesian-speaking students, most participants (75\%) agreed that teachers should use English and Indonesian. Fifteen per cent (15\%) indicated that the language of instruction should use only English. This finding is in line with Mehisto (2008) that language instruction was delivered through English. Furthermore, only 10\% of the participants believed that teachers should solely use Indonesian. In short, the majority of the subjects emphasized the use of two languages in the classroom. It is crucial to their perception of bilingual education goals. This study's findings are in line with the study conducted by Muhlisin (2015), revealing that almost all students would like to have both English and Indonesian in their Bilingual class. Besides, they are aware of Indonesian's overuse that might hinder the development of students' proficiency.

Besides, respondents were questioned if the instructions delivered in Indonesian could delay the development of English. In this regard, 30\% of the students agreed that Indonesian instructions could delay English development. On the contrary, support was significantly more substantial for the use of two languages in the classroom. 70\% of the subjects reported that the development of English was not impeded by applying two languages. Such a finding is in line with the previous study conducted by Baratz-Snowden, Rock, Pollack, and Wilder (1998). A mind-dominant part (60\%) expressed their willingness to master both English and Indonesian, stable with their sight that teachers ought to practice two languages for communication or instruction and their conviction that using 2 languages did not block their English development. An unassuming 40\% of the subjects showed their aspiration to improve only English skills. Yet, no student expressed an awareness in learning language proficiency entirely in Indonesian. Since the students' language ability could not be checked, this research could not confirm if their linguistic competence in one or the other English or Indonesian affected their language improvement aspirations.

The study also examined the participants' impression of whether bilingual use in CLIL was helpful for their learning involvement. In this regard, all participants affirmed that it was indeed supportive. When interrogated as to whether they agreed that joining in a CLIL program exaggerated their confidence or fearlessness levels, all respondents shared a similar view that using two different languages (bilingual) affects their confidence or fearlessness levels, either positive or negative influence. $85 \%$ believed that it could improve their esteem and confidence levels, while $15 \%$ responded that it decreased their regard and certainty levels. Interestingly, three-fourths (75\%) acknowledged that CLIL education was contributory to their cognitive and emotional well-being. In 
conclusion, it ratifies the participants' perception that the CLIL program contributed to their academic knowledge.

Less than 25\% believed that the students' English skill ability might be advanced if they have been no longer joined in CLIL even though other participants supported the application of two languages in the classroom. 5\% refused to answer whether their English proficiency would be more significant, and $70 \%$ returned to respond to that question and said that their English proficiency would not be more significant. On the contrary, half of them (50\%) stated that their Indonesian language would be undeveloped if not joining the CLIL program. They confirmed that bilingual education facilitated the students' development of Indonesian. But interestingly, almost half of the participants (45\%)admitted that their Indonesian might be more significant if they no longer took part within the CLIL. At last, $5 \%$ of the participants did not respond to this question. This finding is consistent with the findings of Sia and Dewaele (2006) that self-categorized bilinguals regarded themselves not only as L2 learners but also active users of L2.

There was mind-boggling support for CLIL or bilingual education. All participants (100\%) indicated their support for CLIL. Despite the participants' high support for CLIL, students (20\%) declared that they would like to join non-CLIL programs or non-bilingual education highly. The collected data found that the participants expressed their priority and reason for not joining the CLIL programs. First, CLIL classes were more effective, said by $10 \%$ of them. Second, a fourth of participants (25\%) thought that non-CLIL programs could facilitate keeping and strengthening their Indonesian. Then the regular programs were more interesting than CLIL programs, said by $5 \%$ out of participants. Finally, 5\% also expressed that they were interested in CLIL programs because of being with their classmates. $5 \%$ of the participants stated the reasons for "all of the above," and only ten percent (10\%) refused to answer the question.

Also, forty percent responded by providing their reasons. One said that the implementation of CLIL is going to a regular school because it helps them go to university. Furthermore, it tends to have a cheaper administration and a more engaging atmosphere. Primary research investigated parents' perception of CLIL (Padilla, 2018). They would like to ask their children to enrol in the CLIL program since it could improve their children's motivation and language level. Among those who responded that they preferred to be in CLIL activity, 60\% conveyed an attentiveness to broaden and maintain the English dialect. It indicates that the learners preferred to be taught using their L2 (English) as suggested by previous research such as Cook (2013). Only 5\% thought CLIL was more interesting, and 10\% believed that English as a medium instruction was more effective. None of the participants, however, wanted to be with their buddies. All the above reasons were chosen by $20 \%$, and fortunately, no participant was declining to respond to this question. Finally, $5 \%$ of the participants also expressed other reasons, but the grounds were not mentioned. 


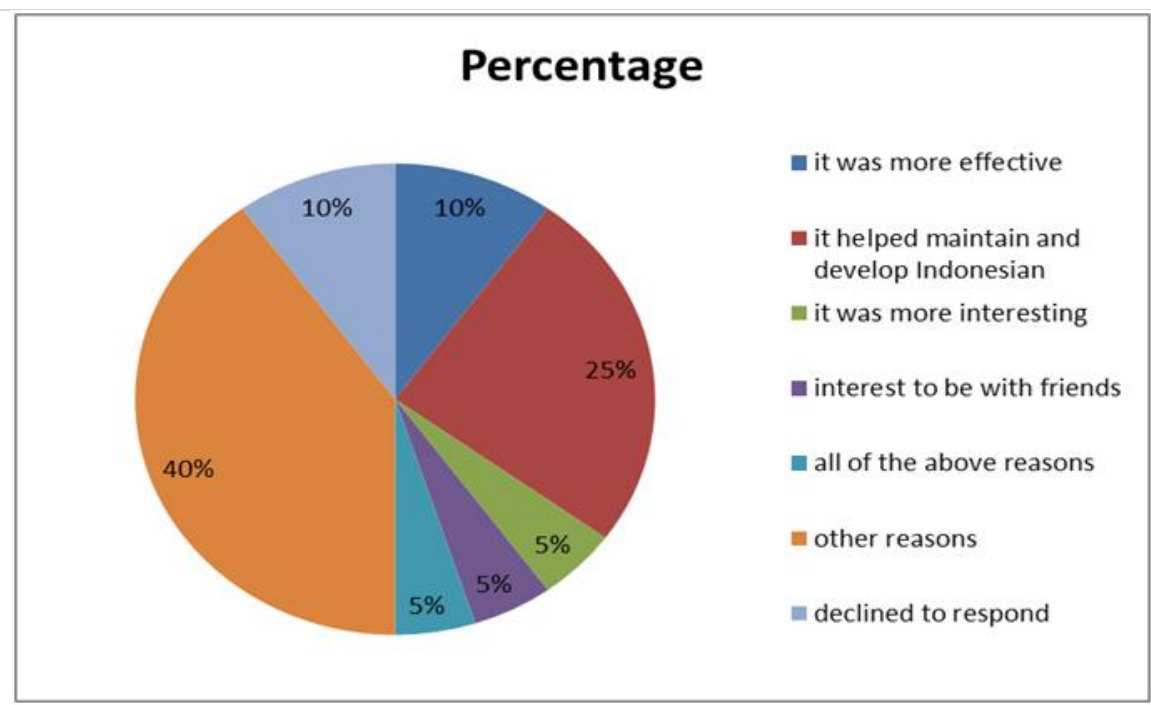

Figure. 1. Students' reasons for not being in a CLIL program

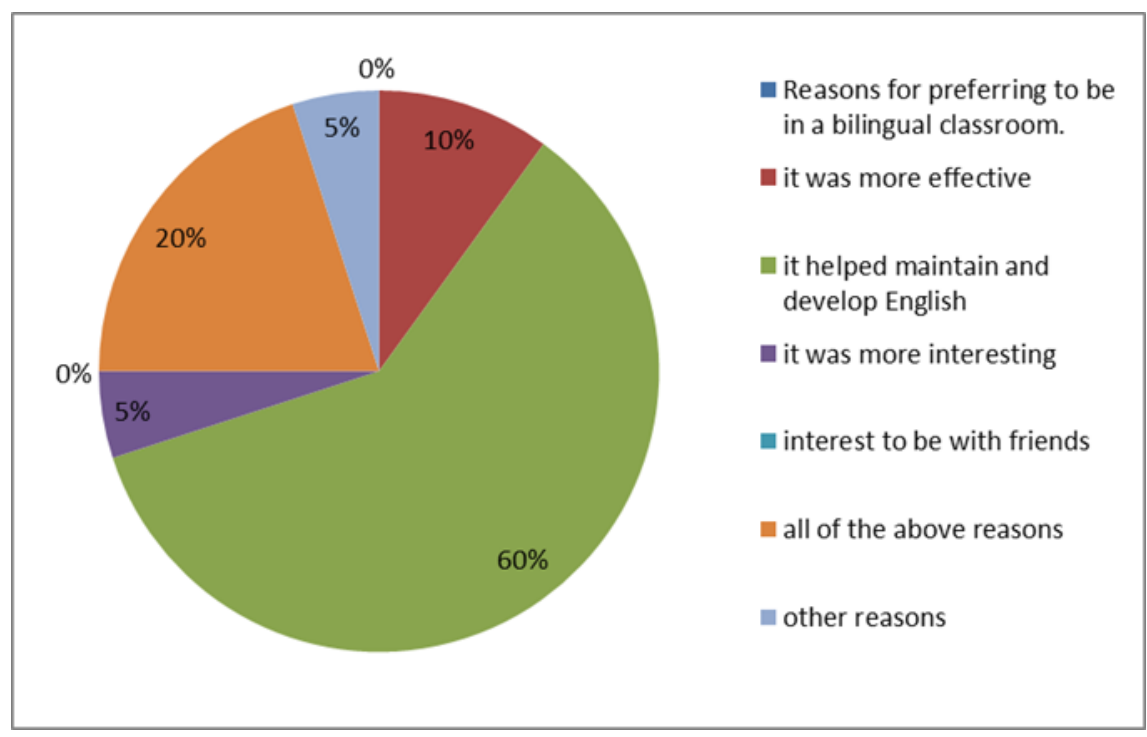

Figure. 2. Students' reasons for being in a CLIL program

The data obtained from the interviews summarized students' responses to the use of two languages in the class. Their responses were excellent, such as stating that bilingual language was appropriate for CLIL implementation (Nikula, 2016; Latsanyphone and Bouangeune, 2009; Kelilo, 2012; Tsukamoto, 2011; Urgal, 2020). The reasons were shifted depending on what they thought, felt, and experienced (Kumar, 2010; Mahmud, 2020). Based on the data from interviews, this research revealed that the implementation of CLIL in a classroom gave certain advantages for the students in some conditions. CLIL facilitated them to communicate with people around, such as their friends, parents, sisters, Muslim preachers, and so on. As Cook (2013) stated that teachers can be the prime model for the communicative use of the second language." In other words, English is useful for them to communicate with other people in this global era. Students indicated that CLIL had benefits depending on the results of the interviews. The benefits were: allowing them to be more confident to speak English; allowing them to be able to preach about Islam to foreigners; improving their skills in English, especially in listening; helping them understand new vocabulary; facilitating them to understand the explanation easily; and allowing them to feel comfortable during class. The sample consisted of participants who were participating in the CLIL class. Their perspectives and arguments are primarily based on their own experience in private schools as CLIL students. From the data of interview and questionnaire sessions, some exciting inferences could be generated. First 
of all, teachers need to notice that what students gave the impression to be their most wanted language did not always match their literacy skills. Even though 20 respondents referred to Indonesian as their number one language, many responded to the questionnaire using English.

There seems to be a typical misunderstanding among CLIL opponents that CLIL is the program in which the instruction is the native language. This research has not reflected the perception: half (50 percent) claimed that the targets of CLIL were to encourage the implementation of English and the Indonesian language. This present research has the same result in which $100 \%$ stated that their English-language skills could be developed by CLIL (i Condom et al., 2009). In reality, of the individuals who reacted that they understood the CLIL class's goals, no student responded that CLIL was to encourage their primary language's progress individually. Thus, in this study, the assumption that CLIL takes away the ability to improve English proficiency was practically unfounded. It is under the previous investigations (Kelilo, 2012). The analysis of the information picked up from the interviews and the questionnaire upheld this finding. Senior high school students' support for English and Indonesian in the classroom (75\%) corresponded with their insight that learning by using two languages did not intermeddle with English development (50 percent). The respondents' support for using the primary language by teachers was minimal (10 percent), consistent with their understanding of CLIL objectives. Curiously, $70 \%$ of students supported bilingual (English and Indonesian language) in the classroom.

The senior high school students' aspirations to develop CLIL are high (60\%), correlating closely to their support for using two languages for classroom instruction by teachers $(75 \%)$. The percentage of those indicating their desire to develop only English (40\%) is not consistent with the percentage of those supporting the use of English exclusively in the classroom (15\%). It suggests that some students believed that a particular language used in the classroom influenced a specific language. Interestingly, a slightly higher percentage of those respondents aspired to develop both languages (English and Indonesian) than those who aspired to develop English only (60\% vs 40\%). Such a finding is in line with the research which reveals that teachers should include some translation into their mother tongue in the classroom (Aguilar \& Rodríguez, 2012).

The most arresting data in this investigation is perhaps the view of all participants (100\%) that CLIL helps their academic experience. It fits pretty well with their support for the implementation of CLIL (100\%). On the other side, while 75\% thought that CLIL supported their affective well-being and cognitive, $15 \%$ did not. They felt that CLIL influenced their confidence or fearlessness levels. Thinking about that, an exquisite percentage (eighty-five percent) of participants acknowledged the significant influence of CLIL. According to them, their levels of self-esteem and self-confidence did not demonstrate whether CLIL could help to strengthen or weaken these levels. These subjects, who are teenagers, may have been unsure about their identities.

Interestingly, the number of those subjects who finished the English version of the questionnaire was $75 \%$. All of them felt that CLIL was helpful for their emotional well-being and cognitive. Therefore, it shows that CLIL may provide more proficient English speakers with better psychological support. The primary research explored linguistic minority parents. Two-thirds of the parents would ask their children to enrol in CLIL programs if the parents were given a preference (Padilla, 2018). Considering that parents highly supported CLIL education, the weakness attached to CLIL was raised as a possible variable affecting parents' desires not to enrol their children in CLIL classes. No proof of stigmatism among learners was found in this study. Just 15\% believed that CLIL had decreased their levels of fearlessness or self-confidence.

The data obtained from specific interview questions showed that most of the students' perception of the CLIL implementation in the classroom was nice. English and Indonesian language (bilingual) was required for English classes, said by the students (Kelilo, 2012; Nikula, 2016; Urgal, 2020; Latsanyphone and Bouangeune, 2009; Tsukamoto, 2011; Dujmovic, 2007). The reasons for what they thought, felt, and passed were shifted to relevant (Foster, 2000). There were also six advantages of bilingualism in the classroom: attempting to make the lesson simple to catch, facilitating children to comprehend and memorize new vocabulary, and improving their English skills. Even though this research found great and positive perceptions of CLIL use in a classroom, a few students in their perception could not help contradicting CLIL implementation in a class. These findings can be interpreted that since students originated from various backgrounds, their CLIL implementation perceptions were also different. 


\section{CONCLUSION}

The students had positive perceptions of the implementation of CLIL in the teaching and learning process, not only in English but also in other subjects. This research's motivation was to give more comprehension about the students' perception of the implementation of CLIL. This investigation has uncovered that students in a school that implements CLIL overwhelmingly bolster the offering of CLIL in government-funded schools. Additionally, most of the learners in CLIL have detailed semantic, social, intellectual, and passionate factors that are basic to class achievement. Thus, this study appears that issues related to language are a critical variable in CLIL. However, to understand the factors that influence either students' or their parents' preferences to implement CLIL at school, further research is recommended. It suggests that the teacher's teaching and learning process should be improved more accurately, such as delivering content and language. Similarly, as it is uncivil to end training in light of difficulties and deficiencies, the discussion on the implementation of CLIL ought not to be about the purpose of either the presence or close of that program, yet about factors detracting from the success of the CLIL program and enhancing the quality of CLIL services accessible to them.

\section{REFERENCES}

Aguilar, M., \& Rodríguez, R. (2012). Lecturer and student perceptions on CLIL at a Spanish university. International Journal of Bilingual Education and Bilingualism, 15(2), 183-197. https://doi.org/10.1080/13670050.2011.615906

Baratz-Snowden, J., Rock, D., Pollack, J., \& Wilder, G. (1998). Parent preference study. Princeton, NJ: Educational Testing Service.

Campillo, J. M., Sánchez, R., \& Miralles, P. (2019). Primary Teachers' Perceptions of CLIL Implementation in Spain. English Language Teaching, 12(4), 149-156. https://doi.org/10.5539/elt.v12n4p149

Cook, V. (2013). Second language learning and language teaching. Routledge.

Coyle, D. (2010). CLIL-A pedagogical approach from the European perspective. In Second and Foreign Language Education: Encyclopedia of Language and Education Volume 4 (pp. 97-111). Springer Science+ Business Media. DOI: 10.1007/978-0-387-30424-3 92

Creswell, J. W., \& Poth, C. N. (2016). Qualitative inquiry and research design: Choosing among five approaches. Sage publications.

Creswell, J. W., \& Creswell, J. D. (2017). Research design: Qualitative, quantitative, and mixed methods approaches. Sage publications.

De Zarobe, Y. R. (2013). CLIL implementation: From policy-makers to individual initiatives. International Journal of Bilingual Education and Bilingualism, 16(3), 231-243. http://dx.doi.org/10.1080/13670050.2013.777383

Dujmović, M. (2007). The use of Croatian in the EFL classroom. Metodički Obzori: Časopis Za Odgojno-Obrazovnu Teoriju i Praksu, 2(3), 91-101. Retrieved from https://hrcak.srce.hr/

Dvorjaninova, A., \& Alas, E. (2018). Implementing content and language integrated learning (CLIL) in Estonia: Subject and language teacher perspective. Eesti Rakenduslingvistika Ühingu Aastaraamat, 14, 41-57. doi:10.5128/ERYa14.03

Foster, J. (2000). The nature of perception. Oxford University Press Oxford.

Hashmi, U. M. (2019). Exploring EFL Teachers' Perceptions of CLIL and Its Implementation in the Saudi EFL Context. International Education Studies, 12(10), 114-122. https://doi.org/10.5539/ies.v12n10p114

Herrarte, D. L., \& Beloqui, R. L. (2015). The impact of type of approach (CLIL versus EFL) and methodology (book-based versus project work) on motivation. Porta Linguarum: Revista Internacional de Didáctica de Las Lenguas Extranjeras, 23, 41-57. DOI: $10.30827 /$ Digibug.53737

Hillyard, S. (2011). First steps in CLIL: Training the teachers. Latin American Journal of Content \& Language Integrated Learning, 4(2), 1-12. DOI: 10.5294/laclil.2011.4.2.1

i Condom, M. F., Codó, E., \& Blanch, M. E. (2009). Enseñar en inglés en la universidad: Reflexiones del alumnado y el profesorado entorno a las experiencias AICLE. Investigar Desde Un Contexto Educativo Innovador, 137-154. Retrieved from https://dialnet.unirioja.es/

Johnson, M. (2012). Bilingual degree teachers' beliefs: A case study in a tertiary setting. 
Kelilo, J. A. (2012). Exploring the use of first language in 'English focus' EFL classroom: Focus on Jimma teachers' college. Unpublished Master's Thesis). Jimma University, Jimma, Ethiopia.

Kumar, R. (2010). The Concept of Perception. Retrieved from http://www.scribd.com/doc/25022575/The-Concept-ofPerception\#scribd

Latsanyphone, S., \& Bouangeune, S. (2009). Using L1 in Teaching Vocabulary to Low English Proficiency Level Students: A Case Study at the National University of Laos. English Language Teaching, 2(3), 186-193. Retrieved from www.ccsenet.org/journal.html

Lee, S. K. (2006). The Latino students' attitudes, perceptions, and views on bilingual education. Bilingual Research Journal, 30(1), 107-122. DOI: 10.1080/15235882.2006.10162868

Mahmud, Y. S. (2020). Conceptualizing Bilingual Education Programs through CLIL and GenreBased Approach: An Indonesian Context. VELES Voices of English Language Education Society, 4(1), 62-74. DOI: 10.29408/veles.v4i1.2005

Marsh, D. (2002). CLIL/EMILE-The European dimension: Actions, trends and foresight potential.

McDougald, J. (2015). Teachers' attitudes, perceptions and experiences in CLIL: A look at content and language. Colombian Applied Linguistics Journal, 17(1), 25-41. http://dx.doi.org/10.14483/udistrital.jour.calj.2015.1.a02

Mehisto, P. (2008). CLIL counterweights: Recognising and decreasing disjuncture in CLIL. International CLIL Research Journal, 1(1), 93-119. Retrieved from http://www.icrj.eu/11/article8.html

Mellado, M. L. (2013). Programas bilingües en Educación Primaria: valoraciones de docentes. Porta Linguarum: Revista Internacional de Didáctica de Las Lenguas Extranjeras, 20, 253-268. DOI: $10.30827 /$ Digibug.22306

Muhlisin. (2015). Teachers' beliefs and students' perceptions on bilingual use in Indonesian EFL classroom: Identity and classroom discourse. Australian Journal of Basic and Applied Sciences, 9: 24, 8-12. Retrieved from www.ajbasweb.com

Nikula, Tarja. (2016). CLIL: A Europian approach to bilingual education. Encyclopedia of Language and Education.

Ockert, D. (2005). Substantive scale verification: A likert scale analysis and critique of university student pedagogical activity preferences. JALT Hokkaido Journal, 9, 48-64. Retrieved from www.researchgate.net

Padilla, J. R. (2018). Parent perspectives on CLIL implementation: Which variables make a difference? Porta Linguarum: Revista Internacional de Didáctica de Las Lenguas Extranjeras, 29, 181-196. DOI: 10.30827/Digibug.54033

Phellas, C. N., Bloch, A., \& Seale, C. (2011). Structured methods: interviews, questionnaires and observation. Researching Society and Culture, 3, 181-205. Retrieved from www.sagepub.com

Puspitasari, E. (2016). Classroom Activities in Content and Language Integrated Learning. Journal of Foreign Language Teaching and Learning, 1(2), 1-13. https://doi.org/10.18196/ftl.129

Sia, J., \& Dewaele, J.-M. (2006). Are you bilingual. Birkbeck Studies in Applied Linguistics, 1, 1-19. Retrieved from https://www.researchgate.net/publication/267798933 Are you bilingual

Syzdykbayeva, R. (2017). Students' attitudes and perceptions of content and language integrated learning in a secondary school. Nazarbayev University Graduate School of Education.

Tachaiyaphum, N., \& Sukying, A. (2017). EFL Pre-Service Teachers' Perceptions of CLIL. Asian Education Studies, 2(4), 44. https://doi.org/10.20849/aes.v2i4.283

Tsukamoto, M. (2011). Students' perception of teachers' language use in an EFL classroom. (10), 143-154. Retrieved from www.semanticsholar.org

Urgal, C. C. (n.d.). Enhancing the implementation of bilingual education at university through practice: Analysis of CLIL trial lessons by an ESP teacher. PAROLE: Journal of Linguistics and Education, 10(1), 46-61. https://doi.org/10.14710/parole.v10i1.46-61 